\title{
Evaluation of Maturity Level Information System And Technology Using Cobit 4.1 (Case Study Diskominfo East Java Province)
}

\author{
Faisal Muttaqin ${ }^{1}$, Firza Prima Aditiawan, Pratama Wirya Atmaja, Fetty Tri Anggraeny, Muhammad Rendy Arief \\ Informatics Engineering \\ Universitas Pembangunan Nasional "Veteran" Jawa Timur \\ Surabaya, Indonesia \\ ${ }^{1}$ faisalmuttaqin.if@upnjatim.ac.id
}

\begin{abstract}
Integrated management and control in the field of technology and communication is an awareness of the importance of the role of information systems and technology in supporting operational activities and services in an organization and government agency. This study will discuss the evaluation of the level of maturity of systems and information technology using Cobit 4.0 at DISKOMINFO (Department of Communication and Information Technology of East Java Province). The purpose of this study is to find out how far the level of maturity of information systems and technology that exist in DISKOMINFO East Java Province. The data collection process was carried out by field observations, interviews and distributing questionnaires. After researching DISKOMINFO East Java Province for the level of maturity of information systems and information technology to get an average value of 3 which means procedures have been standardized and documented and communicated through training. And the method is instructed to be followed, but there may still be irregularities because the procedure is not yet sophisticated.
\end{abstract}

Keywords- Information systems and technology, Cobit 4.1, Maturity Level

\section{INTRODUCTION}

Executives and boards of directors are responsible for IT governance, and consists of leadership, organizational structures and processes that ensure that corporate IT supports and broadens the organization's strategy and goals [1]. The IT function is working to build various capabilities with all organizations that aim to fulfill the organization's strategy. One of its capabilities is to unite internal and external human resources, software applications, hardware, and other resources systematically to achieve the desired results [2]. One of the failures of companies in exploiting the full potential of their IT investments is the lack of alignment or lack of alignment between business and IT strategies in the company [3]. The basis of efficient and effective IT governance is to align the use of IT and the business objectives of the organization [4]. Companies or organizations whose business processes are increasing inevitably have excellent governance. Also information technology is also very instrumental and has a very significant impact on the success of a company or organization [5], [6].

To produce good information technology governance in the use of information technology governance, there are several approaches, namely, the first highlights the basic requirements of IT governance in considering the main methods available. Then the second step is to design a targeted approach that integrates requirements and uses available knowledge management principles. The third step is to describe the use of the approach through a typical illustration application. The three steps of the method can later be used as a tool to assess IT governance within a company or organization that aims to provide a better development direction [7].

Diskominfo East Java Province (Dinas Komunikasi dan Informatika Provinsi Jawa Timur) is a SKPD (Satuan Kerja Perangkat Daerah) which is a brand image in the field of communication and information technology for the East Java Provincial Government in an effort to disseminate information, support the fulfillment of needs and demands and provide services to the community and Other SKPD within the scope of the East Java Provincial Government are efficient, effective, interactive, responsive, transparent, accountable and in accordance with the era of globalization and information disclosure. Based on the results of interviews with the Diskominfo east java province, there were issues and problems related to the low level of awareness about the importance of management in the use of information systems and technology by human resources. From these problems, we as researchers will evaluate maturity level information system and technology using Cobit 4.1 at Diskominfo East Java Province.

\section{LITERATURE REVIEW}

\section{A. Cobit Framework}

Cobit is a framework and supporting tool that allows managers to bridge gaps that relate to control requirements, technical issues and business risks, and communicate the level of control to stakeholders [1]. In addition according to [8] By using a planning system based on COBIT the company can meet external requirements, ensure the security system, 
monitor changes and supervise third parties in protecting customer information from unwanted parties. According to [9] COBIT can also be used to control IT governance processes in financial reporting of an organization or company. Whereas according to [10] the COBIT conceptual model can predict the behavior of auditors in the fields related to them to seek help and provide assistance as evidenced by their posting to the IT audit team.

Cobit's main theme is business orientation. It is designed not only to be practiced by IT service providers, users, and auditors. But the most important thing is to provide comprehensive guidance for management and business process owners. The following is a cobit framework that can be seen in Fig. 1 : In the basic principle of cobit can provide information needed by the company or agency to achieve its objectives, the company also needs to invest and manage and control IT resources that will be used to provide a series of structured processes in providing a service that can provide information to the company. The central heart of the cobit framework is managing and controlling information that aims to help ensure alignment with business needs [1].

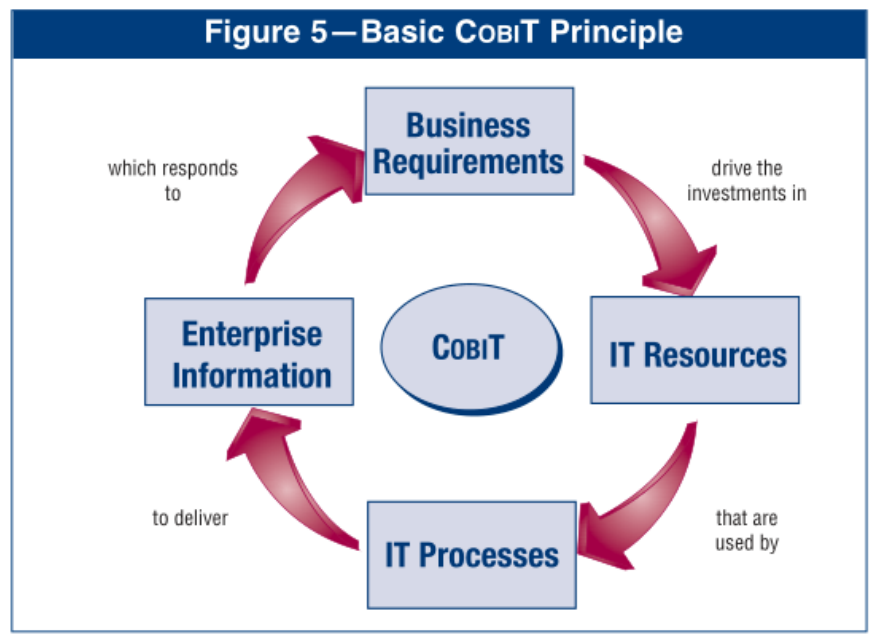

Fig. 1 Basic cobit principle [1]

\section{B. Maturity Model}

A Maturity Model (MM) is a proven technique that can be used to measure different aspects of a process or organization. This is a way to become more organized and systematic in conducting business in organizations. Maturity Model consists of a number of maturity levels, ranging from the lowest value to the highest of which are initial, managed, defined, managed quantitatively and optimally (however, the number of levels themselves can vary depending on the domain and concerns that motivate the model) [11].

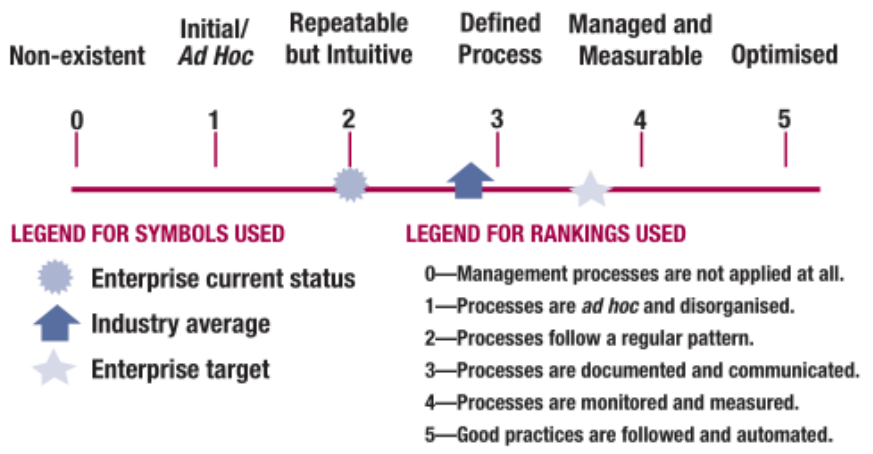

Fig. 2 Graphic representation of maturity models [1]

Using the maturity models developed for each of COBIT's 34 IT processes, management can identify:

- The actual performance of the enterprise-Where the enterprise is today

- The current status of the industry-The comparison

- The enterprise's target for improvement-Where the enterprise wants to be

- The required growth path between 'as-is' and 'to-be'

The following for the model can be seen in Fig. 2. The following is the full explanation regarding points $0-5$ contained in Fig. 2 can be seen in Table I.

\section{TABLE I. Generic MATURITY Model [1]}

\begin{tabular}{|c|c|}
\hline 0 Non-existent & $\begin{array}{l}\text { The company or organization does not care about the } \\
\text { importance of information technology to be managed } \\
\text { properly by management. }\end{array}$ \\
\hline 1 Initial/ Ad Hoc & $\begin{array}{l}\text { There is evidence that companies or organizations feel } \\
\text { there are problems that need to be addressed, but there is } \\
\text { no standard process. Instead there is an ad hoc approach } \\
\text { applied to each individual if problems occur. For a } \\
\text { comprehensive approach, management has not been } \\
\text { regulated. }\end{array}$ \\
\hline $\begin{array}{l}2 \text { Repeatable but } \\
\text { Intuitive }\end{array}$ & $\begin{array}{l}\text { For this time the process has developed because there are } \\
\text { procedures that are followed by everyone. But there has } \\
\text { been no formal training or communication related to } \\
\text { existing standard procedures, and responsibility is } \\
\text { returned to each individual. The existence of a high level } \\
\text { of dependence and differences in knowledge in each } \\
\text { individual to allow errors in its implementation. }\end{array}$ \\
\hline 3 Defined Process & $\begin{array}{l}\text { Procedures have been standardized and documented and } \\
\text { communicated through training. And the procedure is } \\
\text { instructed to be followed, but there may still be } \\
\text { irregularities because the procedure is not yet } \\
\text { sophisticated. }\end{array}$ \\
\hline $\begin{array}{l}4 \text { Managed and } \\
\text { Measurable }\end{array}$ & $\begin{array}{l}\text { The company or organization has monitored and } \\
\text { measured the level of compliance with existing } \\
\text { procedures and took action against processes that did not } \\
\text { function properly. If an error occurs there is an } \\
\text { improvement in each process and provides good } \\
\text { implementation. For automation and the tools used are } \\
\text { still very limited. }\end{array}$ \\
\hline 5 Optimized & $\begin{array}{l}\text { Each process has been refined to a good level of practice } \\
\text { based on the results of continuous improvement and } \\
\text { maturity models with other companies. The existing IT in } \\
\text { the company is well integrated and computerized which } \\
\text { serves to improve the quality and effectiveness of the } \\
\text { company, so that it can quickly adapt }\end{array}$ \\
\hline
\end{tabular}




\section{METHODOLOGY}

The following are the research stages used:

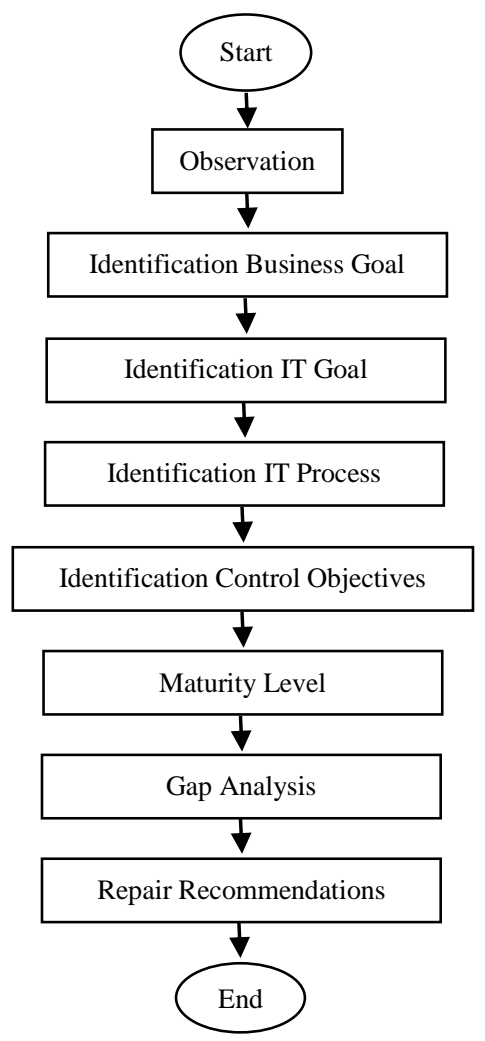

Fig. 3 Research stage

\section{Observation}

At this stage we as observers make observations or visits directly to Diskominfo East Java Province with the aim of knowing the conditions of the agency, so that from the results of these observations we can find a problem for the research material.

\section{Identification Business Goal}

At this stage, the process of analyzing business objectives in Diskominfo east java province will be used to get an idea of where the agency will go. The results of the business objectives will be adjusted and matched according to the business objectives in Cobit 4.1.

\section{Identification IT Goal}

In this step, an identification of information technology will be carried out based on the business objectives of the previously determined agency. The purpose of information technology is obtained by linking business objectives with information technology objectives in Cobit 4.1.

\section{Identification IT Process}

At this stage, there will be the identification of the linkages between the information technology processes in the agency and the information technology process in Cobit 4.1.
At this stage identification of control, objectives will be carried out, where for each IT process there must be different control objectives. The control objective is part of the detail information technology process (IT Process), and not all control objectives in the information technology process are used. Therefore, it is necessary to re-identify what control objectives are needed to support the information technology process in Diskominfo East Java Province.

\section{Maturity Level}

At this maturity level, an assessment of current conditions and expected conditions will be assessed at Diskominfo East Java Province which refers to Cobit 4.1.

\section{Gap Analysis}

At this stage will compare the value of the current condition with the expected condition value. From the results of this analysis will be used to determine what steps need to be taken to move from the current condition to the desired conditions or desired future conditions.

\section{Repair Recommendations}

At this stage, recommendations will be made to improve the conditions of value which according to the agency are still low.

\section{RESULT AND DISCUSSION}

Based on the results of interviews with resource persons, one problem can be drawn, namely the low level of awareness about the importance of management in the use of information systems and information technology by human resources in Diskominfo east java province. From the results of these problems, then the mapping process is carried out and produces six subdomains including the following

- PO2 (Define the Information Architecture)

- PO3 (Determine Technological Direction)

- AI2 (Acquire and Maintain Application Software)

- AI3 (Acquire and Maintain Technology Infrastructure)

- AI5 (Procure IT Resources)

- DS7 (Educate and Train Users)

Once the subdomain is obtained, the next step is to assess the maturity of the current condition and the expected maturity value. The following is the result of the current maturity condition which can be seen in Table II.

Table II. Maturity Value of The CuRrent Conditions

\begin{tabular}{|c|l|c|}
\hline Domain & \multicolumn{1}{|c|}{ Sub Domain } & Level \\
\hline \multirow{2}{*}{ PO } & PO2 (Define the Information Architecture) & 4 \\
\cline { 2 - 3 } & PO3 (Determine Technological Direction) & 2 \\
\hline \multirow{3}{*}{ AI } & AI2 (Acquire and Maintain Application Software) & 3 \\
\cline { 2 - 3 } & $\begin{array}{l}\text { AI3 (Acquire and Maintain Technology } \\
\text { Infrastructure) }\end{array}$ & 2 \\
\cline { 2 - 3 } & AI5 (Procure IT Resources) & 4 \\
\hline DS & DS7 (Educate and Train Users) & 3 \\
\hline \multicolumn{2}{|c|}{ Average } & 4 \\
\hline
\end{tabular}

\section{Identification Control Objectives}


Based on the results of the assessment conducted at Diskominfo East Java Province, for the current condition maturity values in the subdomains PO2, AI5 and DS7 on average get a value of 4 (Managed and Measurable), which mean the company or organization has monitored and measured the level of compliance with existing procedures and took action against processes that did not function properly. If an error occurs, there is an improvement in each process and provides proper implementation. For automation and the tools used are still very limited. Whereas for subdomains AI2 get a value of 3 (Defined Process), which mean Procedures have been standardized and documented and communicated through training. And the procedure is instructed to be followed, but there may still be irregularities because the procedure is not yet sophisticated. Whereas for the PO3 and AI3 subdomains, the average score is 2 (Repeatable but Intuitive), which mean for this time the process has developed because there are procedures that are followed by everyone. But there has been no formal training or communication related to existing standard procedures, and responsibility is returned to each individual. The existence of a high level of dependence and differences in knowledge in each individual to allow errors in its implementation.

After the maturity value of the current condition has been obtained, the next step is to assess the maturity expected by Diskominfo in the province of East Java. The results can be seen in Table III.

TABLE III. The EXPECTED MATURITY VALUE

\begin{tabular}{|c|l|c|}
\hline Domain & \multicolumn{1}{|c|}{ Sub Domain } & Level \\
\hline \multirow{2}{*}{ PO } & PO2 (Define the Information Architecture) & 5 \\
\cline { 2 - 3 } & PO3 (Determine Technological Direction) & 3 \\
\hline \multirow{3}{*}{ AI } & AI2 (Acquire and Maintain Application Software) & 4 \\
\cline { 2 - 3 } & $\begin{array}{l}\text { AI3 (Acquire and Maintain Technology } \\
\text { Infrastructure) }\end{array}$ & 3 \\
\cline { 2 - 3 } & AI5 (Procure IT Resources) & 5 \\
\hline DS & DS7 (Educate and Train Users) & 5 \\
\hline
\end{tabular}

After the expected maturity value has been obtained, the next step is to do a gap analysis by reducing the maturity value expected with the current maturity value. The results can be seen in Table IV.

TABLE IV. GAP VALUE

\begin{tabular}{|c|c|c|c|}
\hline $\begin{array}{c}\text { Sub } \\
\text { Domain }\end{array}$ & $\begin{array}{c}\text { value of the current } \\
\text { condition maturity } \\
(\mathbf{A})\end{array}$ & $\begin{array}{c}\text { expected } \\
\text { maturity value } \\
(\mathbf{B})\end{array}$ & $\begin{array}{c}\text { Gap Analysis } \\
(\mathbf{B}-\mathbf{A})\end{array}$ \\
\hline $\mathrm{PO} 2$ & 4 & 5 & 1 \\
\hline $\mathrm{PO} 3$ & 2 & 3 & 1 \\
\hline $\mathrm{AI} 2$ & 3 & 4 & 1 \\
\hline $\mathrm{AI} 3$ & 2 & 3 & 1 \\
\hline $\mathrm{AI} 5$ & 4 & 5 & 1 \\
\hline $\mathrm{DS} 7$ & 4 & 5 & 1 \\
\hline
\end{tabular}

Based on Table IV. We can see the average for the obtained gap analysis that is the value of 1 . With the value of the gap can later help researchers to provide recommendations for improvement to achieve the expected maturity value to Diskominfo in the province of East Java. The following results if made in graphical form can be seen in Fig. 4.

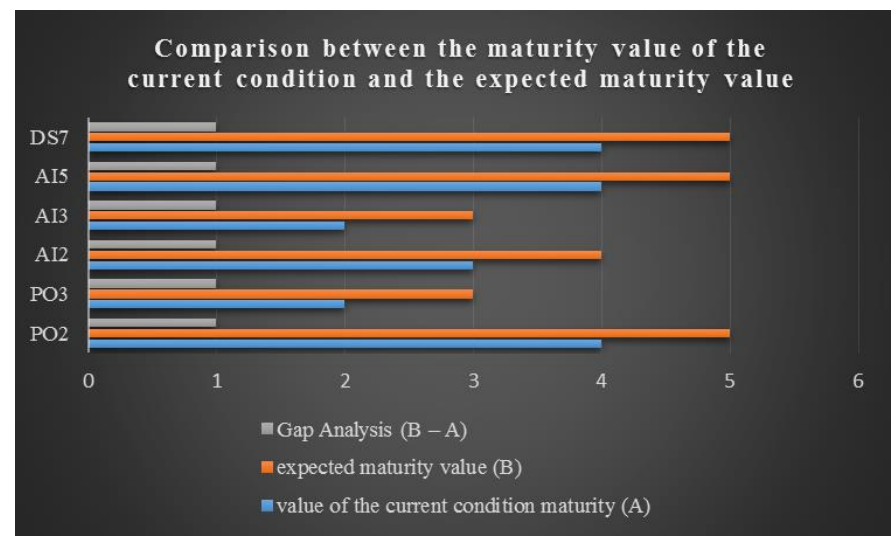

Fig. 4 Comparison between the maturity value of the current condition and the expected maturity value

\section{CONCLUSION}

From the results of research that has been conducted at Diskominfo East Java Province can draw conclusions, namely for the maturity value of the current condition in the subdomains PO2, AI5 and DS7 on average get a value of 4 (Managed and Measurable), while for subdomains AI2 gets a value of 3 (Defined Process), and for PO3 and AI3 subdomains, the average score is 2 (Repeatable but Intuitive). In addition, based on the results of the research that has been carried out, it will produce a recommendation aimed at the process of development and improvement at Diskominfo East Java Province.

\section{REFERENCES}

[1] ITGI, COBIT 4.1: Framework, control objectives, manag. guidel. matur. model.. 2007.

[2] R. Debreceny and G.L. Gray, "IT governance and process maturity: A field study," Proc. Annu. Hawaii Int. Conf. Syst. Sci., HICSS, pp. 1-10, 2009.

[3] E. Silva and Y. Chaix, "Business and IT governance alignment simulation essay on a business process and IT service model," Proc. Annu. Hawaii Int. Conf. Syst. Sci., pp. 1-11, 2008.

[4] G. Ridley, J. Young, and P. Carroll, "COBIT and its utilization: a framework from the literature," 37th Annu. Hawaii Int. Conf. Syst. Sci. 2004. Proc., vol. 00, no. C, p. 8 pp., 2004.

[5] B. Tonn and D. Stiefel, "The future of governance and the use of advanced information technologies," Futures, vol. 44, no. 9, pp. 812 822, 2012.

[6] A. Prasad, J. Heales, and P. Green, "A capabilities-based approach to obtaining a deeper understanding of information technology governance effectiveness: Evidence from IT steering committees," Int. J. Account. Inf. Syst., vol. 11, no. 3, pp. 214-232, 2010.

[7] H. Bin-Abbas and S.H. Bakry, "Assessment of IT governance in organizations: A simple integrated approach," Comput. Human Behav., vol. 32, pp. 261-267, 2014.

[8] S.M. Huang, W.C. Shen, D.C. Yen, and L.Y. Chou, "IT governance: Objectives and assurances in internet banking," Adv. Account., vol. 27, no. 2, pp. 406-414, 2011.

[9] D.S. Kerr and U.S. Murthy, "The importance of the CobiT framework IT processes for effective internal control over financial reporting in organizations: An international survey," Inf. Manag., vol. 50, no. 7, pp. 590-597, 2013. 
[10] B. Tuttle and S.D. Vandervelde, "An empirical examination of CobiT as an internal control framework for information technology," Int. J. Account. Inf. Syst., vol. 8, no. 4, pp. 240-263, 2007.

[11] D. Proença and J. Borbinha, "Maturity Models for Information Systems - A State of the Art," Proc. Comput. Sci., 2016, vol. 100, no. 2, pp. 1042-1049. 